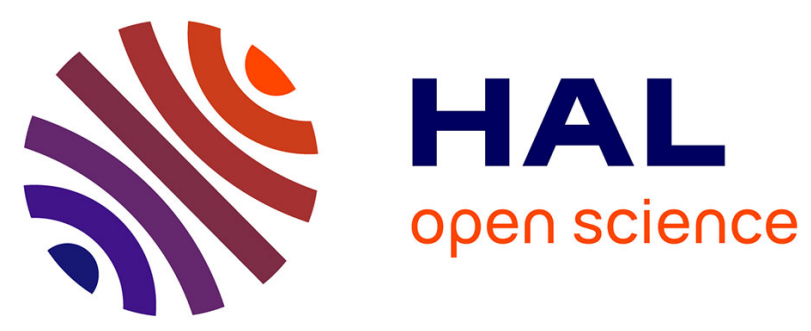

\title{
Preparation of High Purity Metals by Crystallization Methods
}

\author{
J. Drápala, L. Kuchar, M. Kursa
}

\section{To cite this version:}

J. Drápala, L. Kuchar, M. Kursa. Preparation of High Purity Metals by Crystallization Methods. Journal de Physique IV Proceedings, 1995, 05 (C7), pp.C7-143-C7-148. 10.1051/jp4:1995713 . jpa00254006

\section{HAL Id: jpa-00254006 https://hal.science/jpa-00254006}

Submitted on 1 Jan 1995

HAL is a multi-disciplinary open access archive for the deposit and dissemination of scientific research documents, whether they are published or not. The documents may come from teaching and research institutions in France or abroad, or from public or private research centers.
L'archive ouverte pluridisciplinaire HAL, est destinée au dépôt et à la diffusion de documents scientifiques de niveau recherche, publiés ou non, émanant des établissements d'enseignement et de recherche français ou étrangers, des laboratoires publics ou privés. 


\title{
Preparation of High Purity Metals by Crystallization Methods
}

\author{
J. Drápala, L. Kuchă and M. Kursa \\ Institute of Mining and Metallurgy, Technical University, Ostrava, Czech Republic
}

\begin{abstract}
This paper presents limit values of equilibrium distribution coefficients of admixtures in basic metals and the periodical correlation dependences of the distribution coefficients. For high melting-point metals activation neutron analysis, X-ray topography and SSMS were applied to establish effective distribution coefficients of selected admixtures in metals as well as the structural perfection of single crystals.
\end{abstract}

\section{INTRODUCTION}

High purity metals with high or medium melting temperature are nowadays remelted in arc, plasma, ion, electron beam and other furnaces. The refining effects of these melting methods are controlled by crystallization processes on the crystal-melt boundary (normal freezing, zone melting, Czochralski method, etc).

Calculation of the solidus and liquidus curves in binary system A-B, was worked out by Kuchar [1]. These curves are - especially in the region adjacent to the essential component - expressed in the form of polynomials of the second grade [2-5]. The equilibrium state is controlled by thermodynamical regularities.

\section{DISTRIBUTION COEFFICIENT}

The distribution coefficient is defined as an isothermal ratio of admixture concentration on the solidus curve $\mathrm{X}_{\mathrm{S}}$ and on the liquidus curve $\mathrm{X}_{\mathrm{L}}$ in binary element-admixture system $\mathrm{k}_{0}=\mathrm{X}_{\mathrm{S}} / \mathrm{X}_{\mathrm{L}}$ respectively, as its limit value $\mathrm{k}_{0} \lim$ for $\mathrm{X} \rightarrow 0$. The equilibrium distribution coefficient takes the values $\mathrm{k}_{0}>1$ for systems, in which the admixture causes a temperature rise of the basic component, and the values $\mathrm{k}_{0}<1$ for those admixtures causing a temperature drop of the basic component.

Equilibrium distribution coefficients characterize the behaviour and segregation of admixtures during crystallization at the solidus-liquidus interface, refining processes, preparation of single crystals and the study of inhomogeneities in real alloys. Some gave us reliable information about the distributing ability of individual admixture elements in the basic matter in crystallization processes during which the admixture with $k_{0}>1$ are enriched on the axes of crystallizing dendrites, and vice versa, the admixtures with $k_{0}<1$ are enriched in interdendritic spaces and in the finally solidifying mother melts during the dendritic segregation which always accompanies solidification of substances in reality. In selective refining metallurgical crystallization processes used to prepare high purity metals (as well as substances and metal single crystals, such as zone melting or normal freezing with the material removal) an effective distribution of admixtures in their successive accumulation occurs, so that admixtures with $\mathrm{k}_{0}>1$ accumulate at the beginning and admixtures with $\mathrm{k}_{0}<1$ at the end of the refined ingot. A knowledge of distribution coefficient values is important for prediction of the refining efficiency in view of the fact that the purity can be influenced [6-12]. Our paper presents a systematic study of the solidus and liquidus curves of available binary systems for these 50 basic elements and 3 compounds:

- Iron Fe

- Non-ferrous metals $\mathrm{Co}, \mathrm{Ni}, \mathrm{Cu}, \mathrm{Ga}, \mathrm{Cd}, \mathrm{In}, \mathrm{Sn}, \mathrm{Sb}, \mathrm{Pb}, \mathrm{Te}$

- Light metals Al

- Noble metals Ag, Au, Ru, Rh, Pd, Os, Ir, Pt

- Refractory metals Ti, Zr, Hf, V, Nb, Ta, Cr, Mo, W, Re

- Lanthanoids La, Ce, Pr, Nd, Sm, Gd, Tb, Dy, Ho, Er, Tm, Yb, Lu and Sc, Y

- Radioactive metals $U, T h, P u$ 
Table 1. Distribution coefficients of admixtures in $\mathrm{Al}, \mathrm{Ti}, \mathrm{Fe}, \mathrm{Ni}, \mathrm{Cu}, \mathrm{Nb}, \mathrm{Mo}, \mathrm{Ag}, \mathrm{La}, \mathrm{U}$

\begin{tabular}{|c|c|c|c|c|c|c|c|c|c|c|c|}
\hline \multicolumn{2}{|c|}{ Element } & \multirow{2}{*}{$\frac{\text { Al }}{<0.1}$} & \multirow[t]{2}{*}{$\pi i$} & $\mathrm{Fe}$ & $\mathrm{Ni}$ & $\mathrm{Cu}$ & $\mathbf{N b}$ & Mo & $\mathrm{Ag}$ & La & $u$ \\
\hline 1 & $\mathrm{H}$ & & & $\sim 0.3$ & & 0.6 & & & & 1.15 & 0.60 \\
\hline 2 & $\mathrm{He}$ & $<0.001$ & $<0.001$ & $<0.001$ & $<0.001$ & $<0.001$ & $<0.001$ & $<0.001$ & $<0.001$ & $<0.001$ & $<0.001$ \\
\hline 3 & $\mathrm{Li}$ & 0.58 & & & & 0.45 & & & 0.50 & $>1$ & $<0.1$ \\
\hline 4 & $\mathrm{Be}$ & 0.30 & 0.12 & 0.62 & 0.36 & 0.34 & & 0.041 & 0.32 & & 0.34 \\
\hline 5 & B & 0.26 & & 0.046 & 0.0062 & 0.057 & 0.041 & 0.12 & & & $<0.1$ \\
\hline 6 & $c$ & & 0.37 & 0.13 & 0.22 & $\sim 0.1$ & 0.62 & 0.065 & & 0.36 & 0.20 \\
\hline 7 & $N$ & $<0.1$ & & & & & $\sim 0.8$ & & & $>1$ & $<0.1$ \\
\hline 6 & 0 & & 1.65 & 0.13 & 0.016 & 0.023 & 0.22 & & $\sim 0.01$ & $>1$ & 0.088 \\
\hline 9 & $F$ & & & & & & & & & & \\
\hline 10 & $\mathrm{Ne}$ & $<0.001$ & $<0.001$ & $<0.001$ & $<0.001$ & $<0.001$ & $<0.001$ & $<0.001$ & $<0.001$ & $<0.001$ & $<0.001$ \\
\hline 11 & $\mathrm{Na}$ & 0.018 & & & & & $\sim 0.01$ & & & $>1$ & \\
\hline 12 & $\mathrm{Mg}$ & 0.30 & & 0.17 & 0.18 & 0.11 & 0.050 & & 0.56 & 0.60 & $<0.1$ \\
\hline 13 & $\mathrm{Al}$ & 1.00 & 1.37 & 0.87 & 0.87 & 0.95 & 0.45 & 0.44 & 0.49 & $<0.1$ & 0.57 \\
\hline 14 & $\mathrm{Si}$ & 0.10 & 0.36 & 0.84 & 0.36 & 0.43 & 0.16 & 0.19 & $<0.1$ & & 0.14 \\
\hline 15 & $P$ & $<0.1$ & 0.033 & 0.13 & 0.0061 & 0.11 & & & $<0.1$ & & \\
\hline 16 & $s$ & $<0.01$ & 0.00081 & 0.055 & 0.0015 & $\sim 0.01$ & & & $\sim 0.01$ & $<0.1$ & $<0.1$ \\
\hline 17 & $\mathrm{Cl}$ & & & & & & & & & $<0.1$ & \\
\hline 18 & Ar & $<0.001$ & $<0.001$ & $<0.001$ & $<0.001$ & $<0.001$ & $<0.001$ & $<0.001$ & $<0.001$ & $<0.001$ & $<0.001$ \\
\hline 20 & $\mathrm{Ca}$ & D. 055 & & & $<0.1$ & 0.05 & & & $<0.1$ & 0.62 & \\
\hline 21 & Sc & $<1$ & 0.38 & 0.057 & 0.048 & $\sim 0.1$ & $<0.1$ & $\sim 0.1$ & 0.45 & 0.88 & \\
\hline 22 & $\mathrm{Ti}$ & 9.40 & 1.00 & 0.34 & 0.73 & 0.35 & 0.59 & 0.74 & $\sim 1$ & $<1$ & $\sim 1.5$ \\
\hline 23 & $v$ & 5.80 & 0.74 & 0.82 & 0.97 & $>1$ & 0.65 & 0.75 & $\sim 1$ & 0.24 & 0.56 \\
\hline 24 & $\mathrm{Cr}$ & 1.84 & 0.60 & 0.90 & 0.82 & 0.54 & 0.82 & 0.71 & $\sim_{1}$ & $<0.1$ & 0.17 \\
\hline 25 & $\mathrm{Mn}$ & 0.76 & 0.31 & 0.68 & 0.72 & 0.37 & & $\sim 0.2$ & $>1$ & 0.038 & 0.17 \\
\hline 26 & $\mathrm{Fe}$ & 0.023 & 0.26 & 1.00 & 0.94 & 1.32 & 0.20 & 0.48 & $>1$ & 0.032 & 0.099 \\
\hline 27 & Co & 0.024 & 0.20 & 0.85 & 1.03 & 1.53 & 0.054 & 0.29 & $>1$ & $<0.1$ & 0.054 \\
\hline 28 & $\mathrm{Ni}$ & 0.0071 & 0.19 & 0.69 & 1.00 & 1.68 & 0.055 & 0.15 & $>1$ & $<0.1$ & 0.029 \\
\hline 29 & $\mathrm{Cu}$ & 0.14 & 0.19 & 0.80 & 0.82 & 1.00 & 0.022 & & 0.51 & $<0.1$ & $<0.1$ \\
\hline 30 & $\mathrm{Zn}$ & 0.43 & & 0.77 & 0.61 & 0.72 & & & 0.38 & $<0.1$ & $<0.1$ \\
\hline 31 & $\mathrm{Ga}$ & 0.088 & 0.73 & 0.76 & 0.63 & 0.59 & 0.33 & $\sim 0.1$ & 0.36 & 0.32 & $<0.1$ \\
\hline 32 & $\mathrm{Ge}$ & 0.080 & 0.74 & 0.77 & 0.52 & 0.40 & 0.21 & 0.15 & 0.23 & $<0.1$ & 0.26 \\
\hline 33 & As & $<0.1$ & 0.074 & 0.20 & 0.084 & 0.19 & & & 0.16 & & \\
\hline 34 & $\mathrm{Se}$ & $<0.01$ & & & & & & & & & \\
\hline 36 & $\mathrm{Kr}$ & $<0.001$ & $<0.001$ & $<0.001$ & $<0.001$ & $<0.001$ & $<0.001$ & $<0.001$ & $<0.001$ & $<0.001$ & $<0.001$ \\
\hline 38 & $\mathrm{sr}$ & $<0.1$ & & & $<0 . t$ & $\sim 0.025$ & & & $<0.1$ & & \\
\hline 39 & $Y$ & 0.028 & 0.10 & 0.054 & 0.053 & 0.056 & & $\sim 0.05$ & 0.17 & 1.60 & \\
\hline 40 & $\mathrm{Zr}$ & 2.24 & 0.75 & 0.035 & 0.086 & 0.02 & 0.57 & 0.26 & $<1$ & & 1.92 \\
\hline 41 & $\mathrm{Nb}$ & 4.18 & 1.23 & 0.22 & 0.51 & 1.90 & 1.00 & 0.80 & & 1.28 & 2.27 \\
\hline 42 & Mo & 2.47 & 1.71 & 0.72 & 0.89 & $\sim_{3}$ & 0.73 & 7.00 & & $>1$ & 1.34 \\
\hline 43 & $\mathrm{Tc}$ & $<1$ & & 1.03 & 1.13 & $>1$ & & & & & \\
\hline 44 & $\mathrm{Ru}$ & $<1$ & 0.53 & 1.03 & 1.20 & $>1$ & 0.47 & 0.60 & $>1$ & & 0.23 \\
\hline 45 & $\mathrm{Rh}$ & $<0.1$ & 0.32 & 0.76 & 1.30 & 2.13 & 0.35 & 0.34 & $>1$ & $<1$ & 0.20 \\
\hline 46 & $\mathrm{Pd}$ & $<0.1$ & 0.33 & 0.47 & 0.52 & 1.09 & 0.54 & 0.21 & 1.94 & & 0.32 \\
\hline 47 & $\mathrm{Ag}$ & 0.34 & 0.68 & & 0.60 & 0.30 & & & 1.00 & 0.22 & \\
\hline 48 & cd & 0.053 & & & $<0.1$ & 0.64 & & & 0.73 & 0.43 & $<0.1$ \\
\hline 49 & $\ln$ & 0.010 & & 0.20 & 0.24 & 0.23 & & & 0.57 & 0.41 & \\
\hline 50 & Sn & 0.0078 & 0.89 & 0.27 & 0.23 & 0.16 & 0.43 & & 0.50 & $<0.1$ & $<0.1$ \\
\hline 51 & $\mathrm{Sb}$ & 0.042 & 0.38 & 0.13 & 0.23 & 0.17 & 0.23 & & 0.21 & $<0.1$ & $<0.1$ \\
\hline 52 & Te & $<0.01$ & & & & 0.001 & & & $<0.01$ & $<0.1$ & \\
\hline 54 & $\mathrm{Xe}$ & $<0.001$ & $<0.001$ & $<0.001$ & $<0.001$ & $<0.001$ & $<0.001$ & $<0.001$ & $<0.001$ & $<0.001$ & $<0.001$ \\
\hline 57 & $\mathrm{La}$ & 0.0032 & 0.42 & 0.044 & $<0.1$ & $\sim 0.06$ & 0.057 & $\sim 0.07$ & 0.0033 & 1.00 & \\
\hline 58 & $\mathrm{Ce}$ & 0.0035 & 0.20 & 0.015 & 0.002 & 0.024 & 0.20 & & 0.052 & 0.90 & 0.13 \\
\hline 59 & Pr & 0.0031 & & & $<0.1$ & $\sim 0.08$ & & & 0.0036 & 1.04 & \\
\hline 60 & $\mathrm{Nd}$ & 0.003 & 0.24 & $\sim 0.11$ & & $\sim 0.07$ & & & 0.018 & 1.10 & \\
\hline 62 & $\mathrm{Sm}$ & $<0.1$ & & 0.0062 & & 0.094 & 0.18 & & 0.035 & 1.52 & \\
\hline 64 & $\mathrm{Gd}$ & & 0.12 & 0.065 & 0.092 & & & 0.072 & 0.055 & 1.59 & \\
\hline 65 & $\mathrm{~Tb}$ & 0.018 & & & & & & & 0.080 & $>1$ & \\
\hline 66 & Oy & $<0.1$ & & & & & & & 0.084 & & \\
\hline 67 & Ho & $<0.1$ & & $<0.1$ & & $<0.1$ & & & 0.090 & & \\
\hline 68 & Er & $<0.1$ & 0.093 & 0.083 & $<0.1$ & & & & 0.239 & $<0.1$ & \\
\hline 69 & $\mathrm{Tm}$ & 0.0081 & & $<0.1$ & & & & & 0.22 & & \\
\hline 70 & $\mathrm{Yb}$ & $<0.1$ & & & & & & & 0.12 & & \\
\hline 71 & Lu & & & $<0.1$ & & & & & 0.29 & & \\
\hline 72 & $\mathrm{Hf}$ & 4.44 & 0.93 & 0.21 & 0.16 & $\sim 0.6$ & 0.79 & 0.58 & $<t$ & & 1.98 \\
\hline 73 & $\mathrm{Ta}$ & $>1$ & 2.17 & 0.32 & 0.74 & $>2$ & 1.27 & 1.05 & & $<0.1$ & 4.42 \\
\hline 74 & $W$ & $>1$ & 3.60 & 0.85 & 0.67 & $>2$ & 1.21 & 1.45 & & & 1.28 \\
\hline 75 & $\mathrm{Re}$ & $>1$ & 1.62 & 1.22 & 1.96 & $>1$ & 0.97 & 0.86 & & & 0.83 \\
\hline 76 & Os & & 0.72 & 1.11 & $>1$ & $>1$ & 0.65 & 0.69 & $>1$ & & 0.50 \\
\hline 77 & Ir & & 0.57 & 1.05 & $>1$ & 2.38 & 0.41 & 0.37 & $>1$ & $<0.1$ & 0.24 \\
\hline 78 & $\mathrm{Pt}$ & 0.44 & 0.31 & 0.60 & 1.032 & 1.72 & 0.055 & 0.24 & 2.45 & & 0.28 \\
\hline 79 & $A u$ & 0.069 & 0.36 & 0.39 & 0.35 & 0.50 & 0.43 & & 1.20 & $<0.1$ & 0.55 \\
\hline 80 & $\mathrm{Hg}$ & 0.12 & & & $\sim 0.1$ & $\sim 0.2$ & & & 0.50 & & $<0.1$ \\
\hline 81 & $\mathrm{TI}$ & $<0.1$ & & & 0.24 & 0.072 & & & 0.20 & 0.36 & \\
\hline 82 & $\mathrm{~Pb}$ & 0.072 & 0.38 & & 0.075 & 0.01 & & & 0.25 & $<0.1$ & $<0.1$ \\
\hline 83 & $8 i$ & 0.039 & 0.36 & & $<0.1$ & 0.001 & & & 0.058 & 0.28 & \\
\hline 86 & Rn & $<0.001$ & $<0.001$ & $<0.001$ & $<0.001$ & $<0.001$ & $<0.001$ & $<0.001$ & $<0.001$ & $<0.001$ & $<0.001$ \\
\hline 90 & $T h$ & 0.050 & & $<0.1$ & 0.002 & 0.084 & & $\sim 0.1$ & $\sim 0.01$ & 1.20 & $<0.1$ \\
\hline 92 & $u$ & 0.0046 & 0.80 & $<0.1$ & 0.034 & $\sim 0.025$ & 0.49 & 0.29 & $\sim 0.05$ & & 1.00 \\
\hline 93 & $\mathrm{~Np}$ & & & & & & & & & & 0.68 \\
\hline 94 & $\mathrm{Pu}$ & 0.0037 & 0.27 & $<0.1$ & 0.093 & $\sim 0.01$ & & $\sim 0.15$ & & 0.70 & 0.54 \\
\hline
\end{tabular}




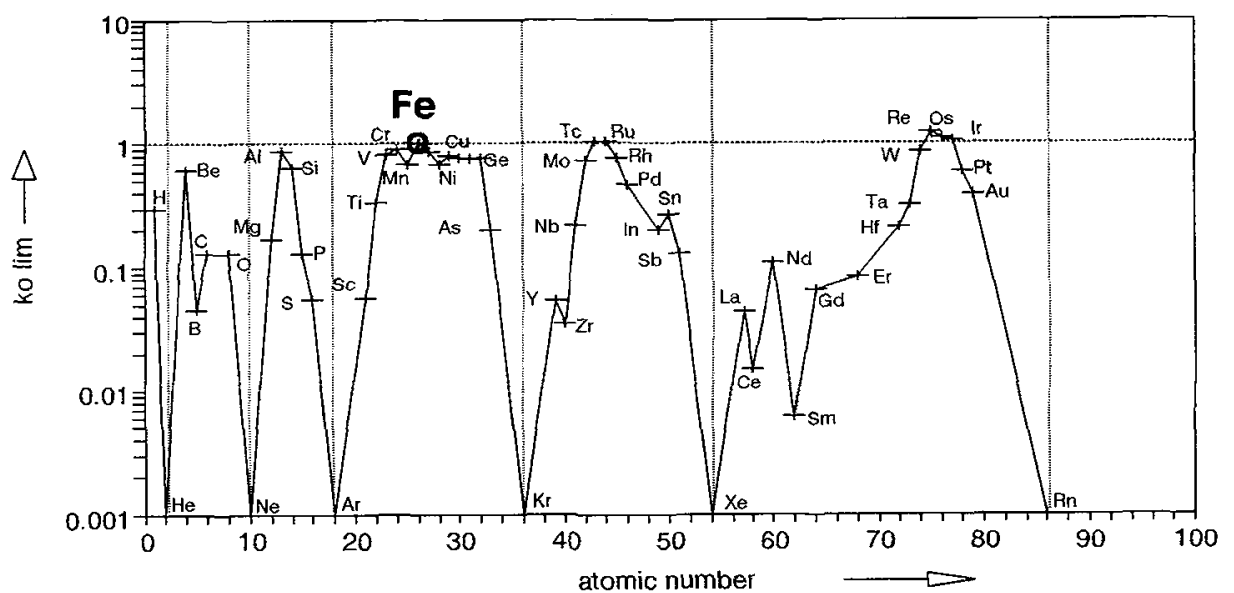

Figure 1: Periodical dependence of distribution coefficients of admixtures in Fe on atomic number

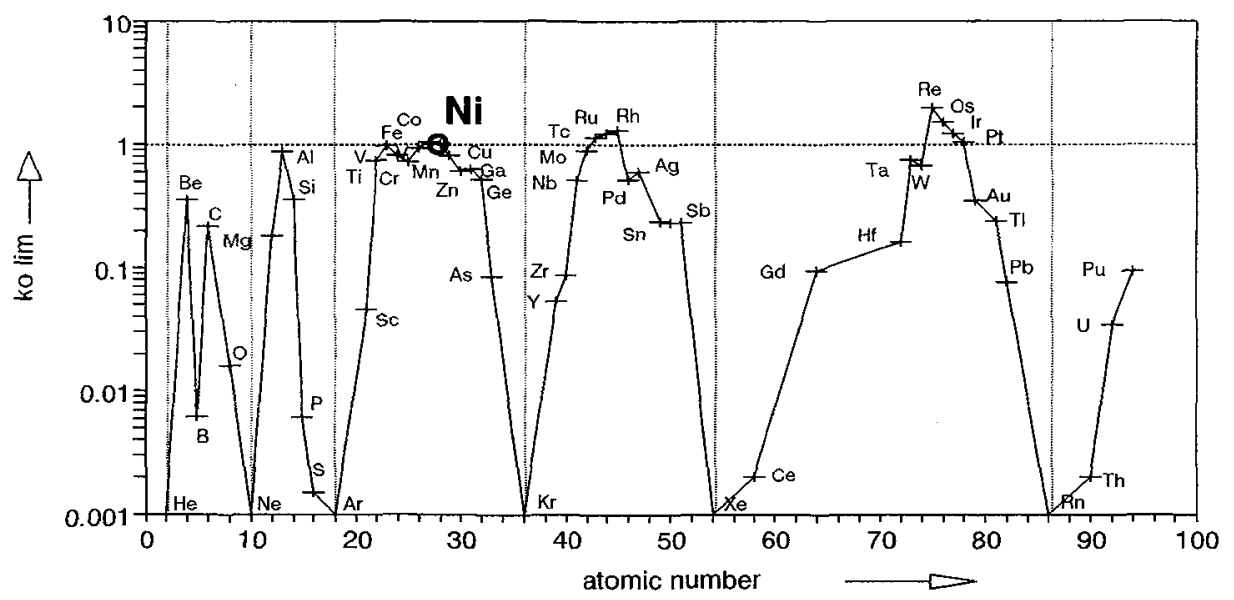

Figure 2: Periodical dependence of distribution coefficients of admixtures in Ni on atomic number

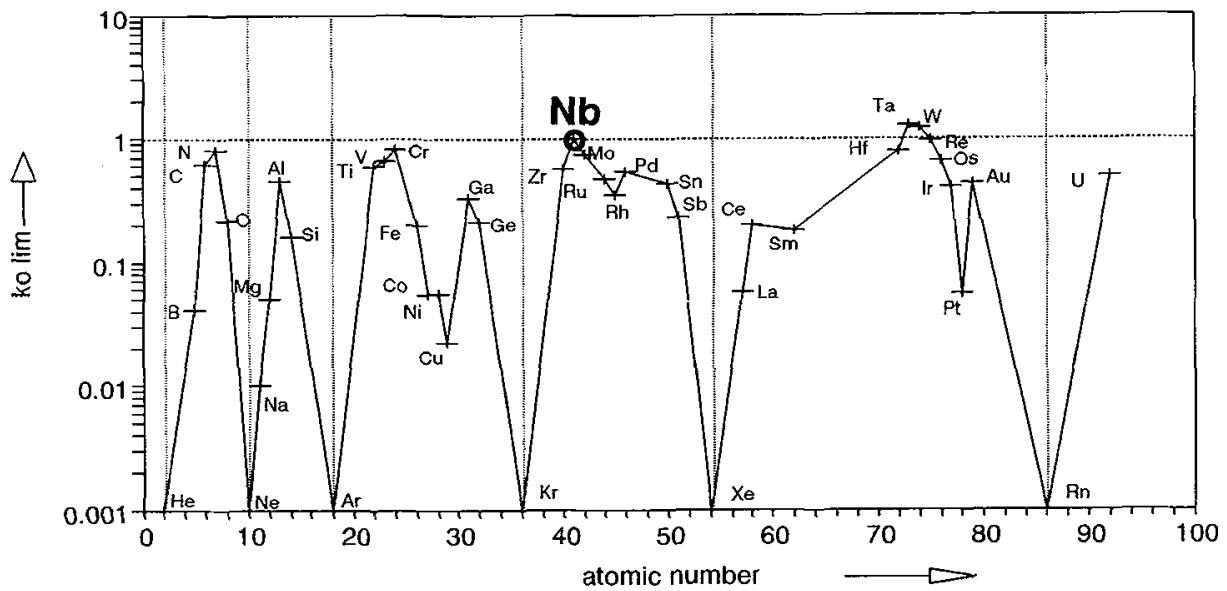

Figure 3: Periodical dependence of distribution coefficients of admixtures in $\mathrm{Nb}$ on atomic number 
- Semiconductors $\mathrm{Si}, \mathrm{Ge}$, and compounds GaAs, GaSb, CdTe

Table 1 presents the values of the equilibrium distribution coefficients of admixtures in 10 basic elements (Al, Ti, Fe, $\mathrm{Ni}, \mathrm{Cu}, \mathrm{Nb}, \mathrm{Mo}, \mathrm{Ag}, \mathrm{La}, \mathrm{U}$ ) obtained from the existing binary alloy phase diagrams as well as from experimentally obtained concentration admixture gradients for which the authors used various melting techniques, such as refining by zone melting or directional crystallization.

\section{PERIODICITY OF DISTRIBUTION COEFFICIENTS}

The values of distribution coefficients may be objectively graphically arranged into a periodical correlation dependence on the atomic number of admixture (fig. 1, 2, 3). Similar periodical dependences were proven by the authors $[1,6,9,11]$ for more than 50 elements of the periodical system [13-16]. These correlation dependences yield a certain periodicity of values $\mathrm{k}_{0}$ in individual periods mutually divided by the value of inert gases $-\mathrm{He},-\mathrm{Ne},-\mathrm{Ar},-\mathrm{Kr},-\mathrm{Xe},-\mathrm{Rn}$ (minima of correlation curves). The maxima of correlation curves are seen in each period.

The values of $\mathrm{k}_{0}$ and correlative relations shown make it possible [6]:

$\rightarrow$ to determine the unknown $\mathrm{k}_{0}$ values and to predict the behaviour of admixtures during crystallization processes

$\rightarrow$ to estimate the practical realization of zone melting or directional crystallization of various basic substances, to choose suitable materials for those processes, and to predict the refining grade

$\rightarrow$ to achieve objective control of crystallization processes in refining metallurgy

$\rightarrow$ to achieve controlled microalloying and doping of admixtures when cultivating single crystals as well as technical alloys in which they increase a number of physical metallurgical properties

$\rightarrow$ to calculate constitutional undercooling in solidifying materials in the crystal-melt boundary

$\rightarrow$ to predict the basic types of binary diagrams

$\rightarrow$ to predict the distribution ability and enriching of foreign admixtures with $\mathrm{k}_{0}>1$ on the dendritus axis and the accumulation of admixtures with $k_{0}<1$ in interdendritic spaces in the mother melt during the dendritic segregation which always accompanies the solidification of substances

$\rightarrow$ to calculate the melting temperature decrease or increase of the basic component at the given admixture concentration

$\rightarrow$ to determine the range of the crystallization interval with respect to the control of the production processes of technical alloys by classic or continuous casting and solidification of substances.

\section{EXPERIMENTAL}

Zone melting and directional crystallization is one of the most effective methods for the preparation of high purity materials. Controlled crystallization is employed for the preparation of oriented single crystals. During zone melting the process of redistribution of impurities occurs at the crystal-melt interface.

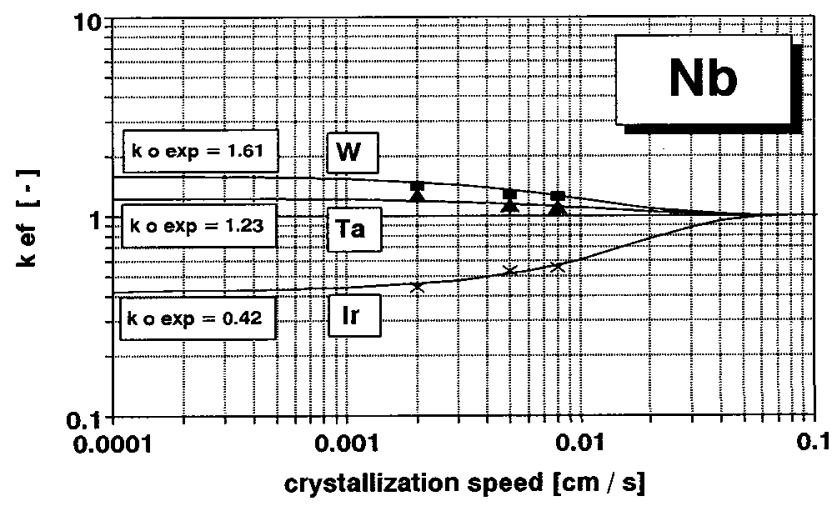

Figure 4: Effective distribution coefficients of W, Ta and Ir in niobium. 
We prepared single crystals of high melting-point metals (W, Mo, Ta, $\mathrm{Nb}, \mathrm{V}, \mathrm{Re}$ ) and their alloys (Nb-Zr, W-Mo, Mo-W, W-Re...) by the method of electron beam zone melting with "floating zone" in our department. The stability of the remelted zone depends on the surface tension, density of the melt, concentration of admixtures and the direction of zone movement. The maximum diameters of single crystal rods, which are prepared using the above-mentioned method, are for molybdenum and niobium $12 \mathrm{~mm}$, for tantalum $10 \mathrm{~mm}$ and for tungsten $6 \mathrm{~mm}$. The length of the single crystal part is $200 \mathrm{~mm}$. We are able to produce single crystals with defined high purity, orientation and structural perfection [17].

Distribution of selected impurities was experimentally performed with nucleides as the indicators during zone melting of metals [18-21]. For high melting-point metals activation neutron analysis was applied to establish effective distribution coefficients in selected admixtures in metals [22].

Effective distribution coefficients $\mathrm{Ir}, \mathrm{Ta}$ and $\mathrm{W}$ in niobium were determined for three different zoning speeds - see fig. 4. Iridium was alloyed into niobium at a concentration of $250 \mathrm{wt} \mathrm{ppm}$. The equilibrium distribution coefficients of Ir, Ta and W in niobium were calculated from these values: $\mathrm{k}_{0}=0.415$ for Ir, which is in good agreement with the theoretical value $\mathrm{k}_{0} \lim =0.409, \mathrm{k}_{0}=1.23$ for $\mathrm{Ta}$, and $\mathrm{k}_{0}=1.61$ for W in niobium. All these experimental values confirmed the periodical dependence of the distribution coefficient values of the admixture on its atomic number [1].

Characteristic macro- and microsegregations in a dependence on the concentration of admixtures and on the molten zone length were found during preparation of molybdenum single crystals alloyed by iridium, which may be imputed to the convection in the molten zone [23]. In Molybdenum single crystals alloyed by iridium at contents between 0,01 - 1,5 at.\% Ir, microinhomogeneities such as crystal cores, striations and cellular structure arise, depending on the crystallization conditions. Dislocation substructure is affected by radial inhomogeneities of the growth cores much more conspicuously than by axial striations or cellular substructure.

Critical concentration $C^{*}=0.2$ at.\% Ir was found for the zone length $4 \mathrm{~mm}$, when the plane surface crystal-melt losts its stability - fig. 5. Iridium is concentrated in the central part of the rod. Developed cellular structure with low dislocation density was observed for concentrations of Ir in molybdenum over 0.4 at.\% (fig. 5).

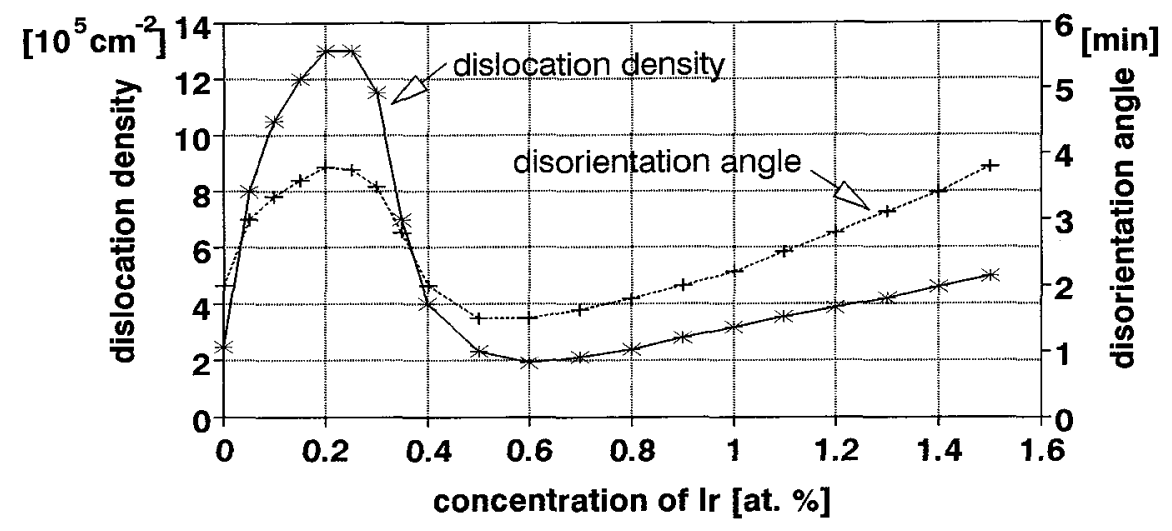

Figure 5: Dependence of dislocation density on concentration of Ir in molybdenum single crystals.

The investigation established that:

a) Zone length (volume of melt) defines the main type of convection - hydrostatic or Marangoni's convections. There are micro-inhomogeneities in the crystal in the form of growth wets or growth cores arising in cases where the critical zone length is exceeded.

b) The crystal structure is influenced by the concentration of admixtures and their distribution in a radial direction.

c) Cellular-fibral structure attains a high degree of structure perfection at defined concentrations of alloyed elements. 
d) Concentration gradients of B-striations influence crystal perfection over the critical concentration of Ir. An inhomogenous structure with a high density of dislocations is created in peripheral areas of crystals.

e) B-cores can be largely eliminated by the use of stimulated convection (rotation, external magnetic field, etc).

A plasma furnace [24], which was developed at the Dept. of Nonferrous Metals TU Ostrava, effects remelting of pure metals with middle and high melting temperature in an inert gaseous atmosphere. The furnace works with a low-temperature plasma burner and a horizontal copper crystallizer with water cooling. It makes it possible to remelt and refine metals ( $\mathrm{Fe}, \mathrm{Co}, \mathrm{Ni}, \mathrm{Ti} .$. ), special highly alloyed alloys (Fe$\mathrm{Si}$, Fe-Ni, Fe-Cr, Fe-Al-Mo, V-N...) and intermetallic compounds (NiTi, Ni3Al, Ti3Al...) [25,26].

\section{CONCLUSION}

Theoretical and experimental results have found a wide variety of applications in various branches of research as well as in practical crystallization and refining processes, by which the significance of the values, not only for metallurgy but also for other new branches of technology, is confirmed.

\section{REFERENCES}

[1] Barthel J., Buhrig E., Hein K. and Kuchař L., Kristallisation aus Schmelzen (VGI Leipzig, 1983) 344 pp.

[2] Vřšstál J. and Kuchař L., Hutnické listy 4 (1990) 286-292.

[3] Kuchař L. and Kuchař L. jr., Hutnické listy 11 (1992) 24-30.

[4] Kuchař L. and Kuchař L. jr., Transactions of the Technical University of Košice, Spec. Issue 2 (1992) 89-99.

[5] Kuchař L. and Drápala J., Int. J. of Materials and Product Technology 1 (1993) 58-70.

[6] Kuchař L., "Importance of distribution coefficients of admixtures in metals for segregations and refining processes", Metal '94, Ostrava 10-12 May 1994 (Tanger, Ostrava, 1994) vol.II, pp. 1-19.

[7] Kuchař L. and Drápala J., Hutnické listy, 7 (1985) 498-507.

[8] Kuchař L. jr., Kuchař L., Drápala J., Burchanov G.S. and Chistyakov O.D., Int. J. of Materials and Product Technology, 4/5/6 (1994) 323-330.

[9] Kuchař L. and Kuchař L. jun., "The distribution coeffitients and their significance for crystallization and refining processes in rare metalls", MatTech 90, TU Helsinki 1990, A Spec. Public. of the Int. J. of Materials and Product Technology UNESCO, M.A. Dorgham and M. Keynes Eds. (United Kingdom, 1991) vol. 3

[10] Drápala J. and Kuchař L., Annales de chimie, science des matériaux 6 (1981) 611-617.

[11] Drápala J., Luňáček J., Kuchař L. and Kuchař L. jr.: Materials Science and Engineering A173 (1993) 73-77.

[12] Drápala J., Inzynieria materialowa 2 (1994) 29-33

[13] Kuchař L., Drápala J. and Wozniaková B., Kovové materiály 1 (1983) 80-89.

[14] Drápala J. and Kuchař L., Kovové materiály 6 (1984) 751-759.

[15] Drápala J. and Kuchař, L., Jaderná energie 8 (1991) 297-306.

[16] Wozniaková B. and Kuchař L., Annales de chimie, science des matériaux 6 (1981) 301-307.

[17] Drápala J. and Kursa M., "On electron beam and plasma metallurgy of metals and alloys", Metal '94, Ostrava 10-12 May 1994 (Tanger, Ostrava, 1994) vol.II, pp. 20-33.

[18] Kuchař L. and Drápala J., Neue Hütte 5 (1979) 185-188.

[19] Drápala J. and Kuchař L., Neue Hütte 4 (1987) 154-156.

[20] Dimitrov O. and Kuchař L., Trans. of Inst. of Mining and Metall. Ostrava 1 (1970) 1-24.

[21] Kuchař L., Drápala J. and Branžovský J., Isotopenpraxis 6 (1984) 207-210.

[22] Kuchař L., Wozniaková B and Drápala J., Journal of Crystal Growth 52 (1981) 359-366.

[23] Drápala J., "Macro- microsegregation and substructure of Mo-Ir single crystals", Metal '95, Ostrava 16-18 May 1995 (Tanger, Ostrava, 1995) vol.III, pp. 55-65.

[24] Dembovský V., Plasma metallurgy (SNTL, Praha, 1978).

[25] Filip P., Čížek L., Kursa M., Kuchař L. and Mazanec K., Trans. of Inst. of Mining and Metall. Ostrava 1 (1988) 125-140.

[26] Kursa M., "Modification of microstructure characteristic of $\mathrm{Ni}_{3} \mathrm{Al}$ ", Metal '95, Ostrava 16-18 May 1995 (Tanger, Ostrava, 1995) vol.III, pp. 44-54. 